\title{
University Students' Perceptions Of Two Countries: Turkey And U.S.A.
}

\author{
Norman V. Schnurr, Robert Morris University, USA \\ Selime Sezgin, Bahcesehir University, Turkey \\ Gulberk Gultekin Salman, Bahcesehir University, Turkey
}

\begin{abstract}
This study was generated to understand how Turkish university students perceive their country and the U.S.A. and how U.S.A. university students perceive their country and Turkey. Perceptions are people's realities, and they use their perceptions to make decisions, form opinions and behave based on them. Perceptions may have tremendous impacts on the economic and political future relations for both countries. The paper was conceived and conducted by university faculty from both Turkey (Bahcesehir University, Istanbul Turkey) and the U.S.A. (Robert Morris University, Pittsburgh, PA). The authors would like to thank their colleagues who had their students complete the surveys.
\end{abstract}

\section{PURPOSE/PROBLEM}

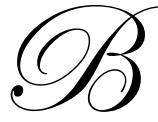

ahcesehir University (BU), Istanbul, Turkey and Robert Morris University (RMU), Pittsburgh, Pennsylvania, U.S.A. have a study abroad agreement. During the several years since this agreement had been in effect, BU students have studied at RMU but no RMU students have opted to study at BU. The hypothesis is that RMU students' perception of Turkey is significantly different from that of BU students. The perceptions of Turkey and the U.S.A. for students at both RMU and BU will be evaluated.

\section{SURVEY/METHODOLOGY}

A questionnaire was designed to be appropriate for both Turkish and American (U.S.A.) students. The Turkish student questionnaire was reverse translated to attempt to standardize the translated Turkish questionnaire. From March 30 to April 16, 2007 undergraduate students at BU (Faculty of Management) and RMU (School of Business) were asked to complete the self-administered questionnaire. BU surveys were completed in $3^{\text {rd }}$ and $4^{\text {th }}$ year undergraduate courses and RMU surveys were completed in some 2 nd year $2^{\text {nd }}$ semester Principles of Marketing courses, but most in $3 \mathrm{rd}$ and $4^{\text {th }}$ year undergraduate courses.

The sample sizes were very large and should be very representative of all upper level business students. (BU 76 students and RMU 471 students).

All data was edited, coded and entered into SPSS for tabulation. Average and standard deviations for each question for BU students and RMU students were calculated.

\section{RESEARCH QUESTIONS \& THOUGHTS}

Is Turkey perceived to be part of Europe or the Middle East?

Obviously one can examine a map of the area to make a determination. However, this may only fuel the confusion of where Turkey lies. Moreover, the political and/or cultural differences in Turkey may add to the confusion. But the biggest question might be - Is where does Turkey want to be ideologically?

Are there differences in the responses by students for eventual resolution of the Palestine and Israel conflict? 
Has the Iraq War had influence on the image of U.S.A. and on the image of Turkey?

How proud are American and Turkish university students of their own country?

Would living in the U.S.A and Turkey be great now and in the future (10 years from now)?

What about the ratings for leadership of both countries?

What are the perceptions of university students about American and Turkish people?

- $\quad$ Are they friendly and likable?

- $\quad$ Are they artistic and creative?

- $\quad$ Are they well-educated?

- Are they hard working?

How open and free are the societies of each country?

How much does religion influence each society?

\section{ANALYSIS \& FINDINGS}

As shown in Table 1, American university students were more likely to put Turkey as part of the Middle East than as part of Europe. Female (U.S.A.) students were even more likely to say Middle East over Europe (Turkish students were not asked this question).

\begin{tabular}{|c|c|c|c|}
\hline \multicolumn{4}{|c|}{ USA Students - Table 1} \\
\hline & $\begin{array}{l}\% \\
10\end{array}$ & $\begin{array}{c}\% \\
10 \& 9 \& 8 \%\end{array}$ & Mean \\
\hline Turkey is a part of Europe & 15.7 & 27.7 & 5.14 \\
\hline Turkey is a part of Middle East Region & 20.5 & 36.2 & 6.15 \\
\hline
\end{tabular}

On a scale of $1-10$

1 = Low score / negative / unlikely

$10=$ High score / positive / likely

Table 2 shows that both Turkish and U.S.A. students were pessimistic over a resolution of the Palestine and Israel conflict in the next two years and American students were more pessimistic than Turkish students. Students from both countries were slightly more optimistic of a resolution within five years.

American and Turkish students felt that the war in Iraq had negatively influenced the image of both countries. Turkish students rated the impact on U.S.A. is image being more negative, as did U.S.A. students on Turkey's image.

\section{USA and Turkey - Table 2}

\begin{tabular}{|c|c|c|c|c|c|c|}
\hline & \multicolumn{3}{|c|}{ Turkey } & \multicolumn{3}{|c|}{ USA } \\
\hline & $\begin{array}{l}\% \\
10\end{array}$ & $\begin{array}{c}\% \\
10 \& 9 \& 8\end{array}$ & Mean & $\begin{array}{l}\% \\
\mathbf{1 0}\end{array}$ & $\begin{array}{c}\% \\
10 \& 9 \& 8\end{array}$ & Mean \\
\hline $\begin{array}{l}\text { Resolution of the Palestine and Israel conflict in } \\
\text { the next two years }\end{array}$ & 1.3 & 3.9 & 3.41 & None & 1.1 & 2.67 \\
\hline $\begin{array}{l}\text { Resolution of the Palestine and Israel Conflict } \\
\text { within five years }\end{array}$ & 1.3 & 14.5 & 4.38 & 0.2 & 2.1 & 3.23 \\
\hline Iraq war's influence on USA's image & 14.5 & 26.3 & 3.83 & 8.1 & 19 & 4.7 \\
\hline Iraq war's influence on Turkey's image & 3.9 & 14.4 & 4.96 & 1.1 & 3.5 & 4.27 \\
\hline
\end{tabular}


Table 2 shows that Turkish and American students were very proud to be citizens of their own country. Turkish students were somewhat more proud to be Turkish than U.S.A. students were to be Americans. Female U.S.A. students tended to be more proud than males.

USA and Turkey - Table 3

\begin{tabular}{|l|c|c|c|c|c|c|c|}
\cline { 2 - 7 } \multicolumn{1}{c|}{} & \multicolumn{3}{|c|}{ Turkey } & \multicolumn{3}{c|}{ USA } \\
\hline & $\mathbf{\%}$ & $\mathbf{\%}$ & Mean & & $\mathbf{\%}$ & $\begin{array}{c}\mathbf{\%} \\
\mathbf{1 0 \& 9 \& 8}\end{array}$ & Mean \\
I am proud to be American & $\mathbf{1 0}$ & $\mathbf{1 0 \& 9 \& 8}$ & & & $\mathbf{1 0}$ & $\mathbf{1 0 8}$ \\
\cline { 2 - 8 } & N/A & N/A & N/A & & 60.5 & 82.8 & 8.91 \\
\hline I am proud to be Turkish & 73.7 & 93.4 & 9.39 & & N/A & N/A & N/A \\
\hline
\end{tabular}

As might be expected, students from Turkey placed Turkey higher as a great place to live than U.S.A. students. Likewise U.S.A. students placed U.S.A. higher as a great place to live.

Turkish students were significantly different than U.S.A. students in their opinion that the U.S.A. presently and in 10 years as a great place to live. As might be expected, U.S.A. students were more positive about the U.S.A. as a great place to live, but became a little more negative about the U.S.A. in 10 years.

Turnabout is fair play in that U.S.A. students did not give high ratings to Turkey as a great place to live now or in 10 years. Turkish students were more positive but not as high as U.S.A. students had given to living in the U.S.A. Turkish students did feel more optimistic about the future of Turkey.

Turkish students gave low ratings to U.S.A. being a very open, free society, but gave even lower ratings to Turkey. U.S.A. students gave high ratings to U.S.A. being a very open, free society and gave lower ratings to Turkey's openness, but gave higher ratings than Turkish students.

Religious influence in each country was felt to be not of great influence by many students, although some Turkish students did feel Turkey was greatly influenced by religion.

U.S.A.'s leadership at the time of the survey was given very low ratings by Turkish students (especially female Turkish students) while U.S.A. students were more positive. Both Turkey and U.S.A. students were on the negative side for ranking Turkey's leadership.

Table 4A

Ratings

Turkish Students

American Students

\begin{tabular}{|c|c|c|c|c|c|c|}
\hline Statement & $\begin{array}{l}\% \\
10\end{array}$ & $\begin{array}{c}\% \\
10+9+8\end{array}$ & Mean & $\begin{array}{l}\% \\
10\end{array}$ & $\begin{array}{c}\% \\
10+9+8\end{array}$ & Mean \\
\hline USA is presently a great place to live & 6.6 & 19.2 & 5.55 & 36.7 & 75.1 & 8.42 \\
\hline In 10 years, USA will be a great place to live & None & 13.7 & 4.63 & 32.9 & 70.7 & 8.14 \\
\hline USA's present leadership & None & 6.6 & 3.43 & 11.3 & 32.5 & 5.88 \\
\hline USA is a very open, free society & None & 12.3 & 4.66 & 28.8 & 67.9 & 8.09 \\
\hline USA is greatly influenced by religion & 6.7 & 24 & 5.15 & 5.1 & 22.1 & 5.78 \\
\hline
\end{tabular}

Turkish students perceive Turkish people to be more friendly and likeable than American people. Turkish students do feel that American people are better educated than Turkish people. In remarks by A. Kohut to Senate Foreign Relations Committee hearing, "Dislike of America undoubtedly reflects dislike of U.S. policies in the Middle East..." (Kohut, 2003) 
American students did not put Turkish people's friendliness as high as their perceptions of themselves. Students from U.S.A. gave higher ratings than Turkish students did for Turkish people being well-educated and hard working. None of the ratings of each others people and their own people were extremely high. Perceptions of Turkish students concerning Americans were lower than their American students' ratings.

Table 4B

Ratings

Turkish Students American Students

\begin{tabular}{|c|c|c|c|c|c|c|}
\hline & \multicolumn{3}{|c|}{ KISII St } & \\
\hline Statement & $\begin{array}{l}\% \\
10 \\
\end{array}$ & $\begin{array}{c}\% \\
10+9+8 \\
\end{array}$ & Mean & $\begin{array}{l}\% \\
10\end{array}$ & $\begin{array}{c}\% \\
10+9+8 \\
\end{array}$ & Mean \\
\hline Turkey is presently a great place to live & 9.2 & 30.2 & 5.76 & 0.2 & 2.1 & 4.12 \\
\hline In 10 years, Turkey will be a great place to live & 11.8 & 32.8 & 6.25 & 0.4 & 5.9 & 4.55 \\
\hline Turkey's present leadership & 2.6 & 11.8 & 4.13 & None & 2.4 & 4.18 \\
\hline Turkey is a very open, free society & 1.3 & 5.2 & 3.57 & 0.4 & 3.2 & 4.15 \\
\hline Turkey is greatly influenced by religion & 23.7 & 51.3 & 7.28 & 5.3 & 24.8 & 5.73 \\
\hline
\end{tabular}

USA and Turkey - Table 5A

\begin{tabular}{|l|c|c|c|c|c|c|c|}
\cline { 2 - 7 } \multicolumn{1}{c|}{} & \multicolumn{3}{c|}{ Turkey } & \multicolumn{3}{c|}{ USA } \\
\cline { 2 - 8 } & $\begin{array}{c}\mathbf{\%} \\
\mathbf{1 0}\end{array}$ & $\begin{array}{c}\mathbf{1 0 8 9 8 8} \\
\mathbf{1 0 8 9}\end{array}$ & Mean & $\begin{array}{c}\mathbf{\%} \\
\mathbf{1 0 \%}\end{array}$ & $\begin{array}{c}\text { Mean } \\
\mathbf{1 0 8 9 \& 8}\end{array}$ \\
\hline Turkish people are friendly and likable & 17.1 & 60.5 & 7.86 & 3.7 & 11.9 & 5.35 \\
\hline Turkish people are artistic and creative & 8 & 25.4 & 5.97 & & 1.8 & 10.6 & 5.36 \\
\hline Turkish people are well educated & 2.6 & 9.2 & 4.39 & 2 & 11.5 & 5.25 \\
\hline Turkish people are hard working & 3.9 & 24.9 & 5.64 & 4.6 & 20.8 & 5.9 \\
\hline
\end{tabular}

\section{USA and Turkey - Table 5B}

\begin{tabular}{|l|c|c|c|c|c|c|}
\cline { 2 - 7 } \multicolumn{1}{c|}{} & \multicolumn{3}{c|}{ Turkey } & \multicolumn{3}{c|}{ USA } \\
\cline { 2 - 8 } \multicolumn{1}{c|}{} & $\begin{array}{c}\mathbf{\%} \\
\mathbf{1 0 \%}\end{array}$ & $\begin{array}{c}\mathbf{1 0 \& 9 8 8} \\
\mathbf{1 0 \%}\end{array}$ & Mean & $\mathbf{\%}$ & $\begin{array}{c}\mathbf{\%} \\
\mathbf{1 0 \& 9 \& 8}\end{array}$ & Mean \\
\hline American people are friendly and likable & 3.9 & 11.8 & 4.83 & 7.7 & 30.9 & 6.6 \\
\hline American people are artistic and creative & 2.7 & 16 & 5.07 & 10.2 & 43.9 & 7.16 \\
\hline American people are well educated & 5.3 & 24.3 & 6.18 & 12.6 & 53.9 & 7.4 \\
\hline American people are hard working & 2.6 & 25 & 5.82 & 12.6 & 49.6 & 7.2 \\
\hline
\end{tabular}

Both sets of students were given an open-ended question: "Can you give me one reason why people may not travel to U.S.A.?' (Turkish students); to Turkey?' (U.S.A. students)

American students indicated the reasons why people may not travel to Turkey:

- $\quad$ Lack of knowledge about the country

- $\quad$ Fear of the unknown

- $\quad$ Concern over violence and/or terrorism

- $\quad$ Too close to problems in the Middle East

Turkish students' reasons why people may not travel to U.S.A.:

- U.S.A.'s limitations of foreign travel after 9/11 - hard to get Visa.

- $\quad$ Preconception of discrimination against Muslims in U.S.A. after 9/11

- Family constraints 
- $\quad$ Distance - long flight

Note: For collection of data, during the time period March 30 and April 16, 2007 there were no significant events that occurred in either Turkey or the U.S.A.

\section{CONCLUSIONS \& FUTURE CONSIDERATIONS}

- The students from both countries perceive issues differently. In most cases ratings were higher or more positive for their own country. A few exceptions:

Turkish students:

- Turkey's present leadership

- Turkey is a very open, free society

- Turkish people are well educated

- Turkish people are hard working

- $\quad$ Male and female students from each country had different perceptions on the same subject:

Turkish students:

- Present leadership of Turkey

- Turkish people hard working

Table 6

Turkish Students

\begin{tabular}{|l|c|c|c|c|c|c|}
\hline \multicolumn{1}{|c|}{ Questions } & All & Male & Std.D. & Female & Std.D. & Sig \\
\hline Turkey's present leadership & 4.13 & 4.59 & 2.783 & 3.3 & 1.958 & 0.011 \\
\hline Turkish people are hardworking & 5.64 & 5.63 & 2.531 & 5.67 & 1.754 & 0.005 \\
\hline
\end{tabular}

T-Test Significance at $\mathrm{p}<0.05$

$\mathrm{n}=76$

U.S.A. students:

- Turkey is part of the Middle East

- U.S.A. is presently a great place to live

- I am proud to be American

Table 7

USA Students

\begin{tabular}{|l|c|c|c|c|c|c|}
\hline \multicolumn{1}{|c|}{ Questions } & All & Male & Std.D. & Female & Std.D. & Sig \\
\hline Turkey is a part of Middle East & 6.15 & 6.08 & 3.003 & 6.25 & 2.707 & 0.041 \\
\hline USA is presently a great place to live & 8.14 & 8.38 & 1.873 & 8.47 & 1.473 & 0.036 \\
\hline I am proud to be an American & 8.91 & 8.79 & 2.064 & 9.08 & 1.53 & 0.002 \\
\hline
\end{tabular}

$\mathrm{n}=471$

T-Test Significance at $\mathrm{p}<0.05$

Whose perceptions were correct --- Turkish students or U.S.A. students? If you can answer this question give us a call. You have more insight than most. Both groups of students have a great deal of concern of each other's country, have a lot of pride in their own country and may need a lot more education on each other's country. During the gathering of data input from the students, many students in both Turkey and the U.S.A. voiced concern that their experiences were very low with the other's country thus their responses were heavily weighted on their perceptions. From a blog archive H. Fine 'In reality, I think Americans' perceptions of Turkey are quite varied, so why do Turks seem to think we Americans see them as very traditional or as dangerous?" (Fine, 2007) The 
intentions of the authors are to conduct the study again --- maybe when some major resolutions of world situations have changed and when each country's leadership has had a change. This study will act as a benchmark so that further conclusions may be drawn. The study could also be broadened to have more college and university students participating.

\section{REFERENCES}

1. Akdemirbey, C. (2006). Is Turkey A Safe Vacation Destination for Americans? AssociatedContent.com.

2. $\quad$ Anonymous (2007). U.S. Education Abroad Numbers Rise, Bu Still Too Low. International Educators. Jan. Feb. Open Doors 2006 Report.

3. Fine, H. (2007). Turkey: Reflection Perceptions. Comparative Religion and Culture - Blog Archive.

4. International Institute of Education. Open Doors. iiEnettworks.org

5. Jenkins, K. (2002). Off the Beaten Path. Black Issues in Higher Education. 19 May, No.6.

6. Kohut, A. (2003). American Public Diplomacy in the Islamic World. The Pew Research Center. Remarks to the U.S.A. Senate Foreign Relations Committee Hearing.

7. Michael, I., Armstrong, A. and King. B.(2003). The Travel Behavior of International Students: the Relationship between Studying Abroad and Their Choice of Tourist Destinations.

8. Pope, H. and Champion, M. (2004). Turkish Attitudes Sour toward U.S.; Poll Shows Doubts in Europe about America's Ability to Lead in Middle East. Wall Street Journal. Eastern Edition. New York, NY. Sept. 9, Pg. A15.

9, Timiraos, N. (2006). Map Widens for Studies Abroad; American Students Seeking a Leg up Step outside Comfort Zone. Wall Street Journal. Eastern Edition. New York, NY. Dec. 19. Pg. B8. 